\title{
Combined study of mineral deposits and deep geothermal for energy production or urban heating - Comparison between the Portuguese (Neves-Corvo) and the Hungarian (Recsk) case studies
}

\author{
József Sas $^{1 *}$, Máté Osvald ${ }^{2}$, Elsa Ramalho ${ }^{3}$, João Xavier Matos ${ }^{4}$ \\ ${ }^{1}$ Faculty of Earth Science and Engineering, Institute of Mineralogy and Geology, University of Miskolc, \\ Miskolc, Hungary \\ ${ }^{2}$ Department of Mineralogy, Geochemistry and Petrology, University of Szeged, Szeged, Hungary \\ ${ }^{3}$ LNEG - National Laboratory for Energy and Geology, Alfragide, Portugal \\ ${ }^{4}$ LNEG - National Laboratory for Energy and Geology, Beja, Portugal
}

Received: May 25, 2017; accepted: February 3, 2018

Energy and metals are essential resources in the 21st century and with the economic and technical development are more and more required. The fulfilling of these requirements leads to the need to produce both more ore and energy. Considering these goals, the project CHPM2030 ("Combined Heat, Power and Metal extraction") was launched in January 2016, focused on the characterization of European mining regions that can be linked to both metal extraction and renewable energy production. The aim of this project is to convert ultra-deep metallic mineral formations into an "orebody-enhanced geothermal system" to coproduce energy and metals. This study will focus on two mining areas (Recsk in Hungary and Neves-Corvo in Portugal), considered CHPM2030 case studies, comparing them regarding mineral (ore) and geothermal potential in terms of heat-flow density values and their implication in temperatures in depth estimations. Especially, when it concerns geothermal energy, the surface demand is an important factor to consider, so wider studies are required.

Keywords: sustainable mining, combined geothermal energy, Neves-Corvo (Portugal), Recsk (Hungary), Combined Heat Power and Metal extraction, CHPM2030

\footnotetext{
*Corresponding author: József Sas; Faculty of Earth Science and Engineering, Institute of Mineralogy and Geology, University of Miskolc, Miskolc-Campus, H-3515 Miskolc, Hungary

E-mail: sas.jozsef1@gmail.com

This is an open-access article distributed under the terms of the Creative Commons Attribution-NonCommercial 4.0 International License, which permits unrestricted use, distribution, and reproduction in any medium for noncommercial purposes, provided the original author and source are credited, a link to the CC License is provided, and changes - if any - are indicated.
} 


\section{Introduction}

The climatic problems and the finite resources of fossil fuels increased the importance of assess and the use of renewable energy sources (Correia and Ramalho 2010). Geothermal resources are part of this sustainable "green" energy; using them is a good opportunity to produce renewable and economic friendly energy (Árpási 2003). Moreover, during this kind of process, less pollution is made, comparing with the fossil fuels. The most important advantage of geothermal energy (among the renewable sources) is that it is weather independent, unlikely the wind or solar power; it can also be continuously extracted and it has a very high capacity factor (Chamorro et al. 2014).

On the other hand, it has some disadvantages. The establishment of geothermal power plants is more expensive than the establishment of traditional ones, but the energy production is cheaper (Árpási 2003). This long-term investment can be the most important drawback of these projects. Furthermore, for producing electricity, the temperature of the fluid has to be at least $90-100{ }^{\circ} \mathrm{C}$ (Lindal 1973). After the water is used, it cannot be released into natural waters, needing to cool down or be reinjected to the reservoir. The conjugate systems can be the best way for the utilization, because the multiple use of fluid (e.g., electricity, heating, agriculture, domestic hot water, or spa) makes it more attractive economically, and during the different uses, the temperature decreases (Dickson and Fanelli 2003).

These sources are not enough (or just some cases) to replace the fossil fuels, but only for additional energy, considering the development of multisource power supply systems. The geothermal potential varies significantly across the earth's surface. There are areas with specific geological settings like Japan, Iceland, or Hungary (Lund and Boyd 2016) and there are places where the potential is low or unavailable for using this kind of alternative energy source. However, in most of the cases, this potential varies at smaller scale distances too, inside a country (Hurter and Haenel 2002).

For geothermal utilization, it is necessary to know several parameters of the reservoir. The most important are the heat-flow density, thermal conductivity, heat production, fluid and salt content, and the geometry of the reservoir (Hurter and Haenel 2002).

However, a new conjugate system is in development, which is focused on mineral deposits. The aim is to produce geothermal energy or urban heating and extract minerals from the geothermal fluid (Project CHPM2030, "Combined Heat, Power and Metal extraction"). This study is focused on two ore deposits, the Neves-Corvo from Portugal Iberian Pyrite Belt (IPB) and Recsk from Hungary.

\section{Applied methodology in geothermal assessment}

"Geothermal resources defined as that part of the geothermal energy which can be extracted economically and legally in the near future" (Hurter and Haenel 2002). Extraction of geothermal resources first requires a through, geological, hydrogeological, and geothermal study. 


\section{Resources}

Energy resources that are presently exploited and demonstrated by drilling or geochemical, geological, and geophysical data are called geothermal reserves. The potential areas are which seem to be adequate to exploitation, but there are not enough data to assess them.

To quantify geothermal resources, some parameters that affect the heat extraction must be estimated. First, the available amount of heat in the rock has to be estimated. This varies significantly in the surface of the earth. Along plate margins, it can be higher and lower in mountainous areas. The average (continental) surface heat-flow density in the world is $65 \mathrm{~mW} / \mathrm{m}^{2}$ (Pollack et al. 1993; Hurter and Haenel 2002). However, there are places like Hungary and the IPB in Portugal, where the geothermal heat flow is higher $\left(80-110 \mathrm{~mW} / \mathrm{m}^{2}\right)$ than the world average (Hurter and Haenel 2002). The second property is the fluid content, which determines the extraction method. If there is fluid in the system, the salt content needs to be known for corrosion protection. Finally, the characteristics of the geothermal reservoir must also be known. The assessment is based on the aquifer knowledge and on the volumetric heat content model for porous reservoirs with a doublet (a production well and an injection well) or singlet (only a production well). The resource $H_{1}$ is given in Joules by the following equation (Hurter and Haenel 2002):

$$
H_{1}=H_{0} \times R_{0},
$$

where $H_{0}$ is the heat contained in place (in Joules) in the reservoir and $R_{0}$ is the recovery factor. The heat contained in the rock matrix by itself and by the fluid, which occupied the pores.

$$
H_{0}=\left[(1-P) \times \rho_{\mathrm{m}} \times c_{\mathrm{m}}+P \times \rho_{\mathrm{w}} \times c_{\mathrm{w}}\right] \times\left(T_{\mathrm{t}}-T_{0}\right) \times A \times \Delta z,
$$

where $\rho_{\mathrm{m}}$ and $\rho_{\mathrm{w}}$ denote the density of the rock matrix and the water $\left(\mathrm{kg} / \mathrm{m}^{3}\right) ; c_{\mathrm{m}}$ and $c_{\mathrm{w}}$, specific heat capacity of the matrix and the water $\left(\mathrm{Jkg}^{-1} \mathrm{~K}^{-1}\right) ; P$, effective porosity; $T_{\mathrm{t}}$, temperature at the top of the aquifer $\left({ }^{\circ} \mathrm{C}\right) ; T_{0}$, temperature at the surface $\left({ }^{\circ} \mathrm{C}\right) ; A$, surface area under consideration $\left(\mathrm{m}^{2}\right)$; and $\Delta z$, net aquifer thickness $(\mathrm{m})$.

The recovery factor $R_{0}$ depends on the extraction technology. If doublet system is used during the exploitation (Hurter and Haenel 2002), then

$$
R_{0}=0.33 \frac{\left(T_{\mathrm{t}}-T_{\mathrm{r}}\right)}{\left(T_{\mathrm{t}}-T_{0}\right)},
$$

where $T_{\mathrm{r}}$ is the reinjection temperature; this value is recommended to be $25{ }^{\circ} \mathrm{C}$ by the European Commission. However, it cannot be used in countries where the average annual temperature is low. The recovery value is reduced to $R_{0} \approx 0.1$ in the case of a singlet (Hurter and Haenel 2002). 
For these calculations, general information about stratigraphy, porosity (from cores or geophysical logging), and geophysical and geological surveys must be known to determine the structures and the geometry of the reservoir.

\section{Heat-flow density and heat production}

The terrestrial heat-flow density describes the vertical heat transport (conductive) in the crust; it can be measured in boreholes. This calculation is based on Fourier's law (Hurter and Haenel 2002):

$$
q=\chi \times \operatorname{grad} T,
$$

where $q$, heat-flow density $\left(\mathrm{W} / \mathrm{m}^{2}\right) ; \chi$, thermal conductivity of rocks $(\mathrm{W} / \mathrm{m} / \mathrm{K})$; and grad $T$, geothermal gradient $\left(\mathrm{K} / \mathrm{m}\right.$ or $\left.{ }^{\circ} \mathrm{C} / \mathrm{m}\right)$.

The geothermal gradient is the temperature variation with depth. The value can be estimated in wells with temperature logs. Thermal conductivity measurements can be made in cores from boreholes or rock samples from outcrops, or estimated from literature or using the results of thermal response tests. Heat-flow density varies significantly across Europe and is usually higher in active volcanic zones with shallower igneous activity (Correia and Ramalho 2005).

For heat production, the uranium, thorium, and potassium concentrations of the rock need to be known. They can be measured by gamma-ray spectrometer or $\mathrm{NaI}(\mathrm{Tl})$ scintillation detector in boreholes or on core samples (Correia and Ramalho 2005).

$$
A=\rho\left(0.097 C_{\mathrm{U}}+0.026 C_{\mathrm{Th}}+0.036 C_{\mathrm{K}}\right),
$$

where $A$, heat production $\left(\mu \mathrm{W} / \mathrm{m}^{3}\right) ; \rho$, the rock density $\left(\mathrm{g} / \mathrm{cm}^{3}\right)$; and $C_{\mathrm{U}}, C_{\mathrm{Th}}$, and $C_{\mathrm{K}}$ are the concentrations of uranium and thorium (both in ppm) and potassium (in \%; Fernández et al. 1998).

These radiogenic elements produce one part of the heat source, during the atomic fissure. The mean heat production value in continental crust is $1 \mu \mathrm{W} / \mathrm{m}^{3}$ for Europe (Hurter and Haenel 2002). The depth temperature values can be directly measured in boreholes or can be calculated from the heat-flow density $\left(\mathrm{W} / \mathrm{m}^{2}\right)$, thermal conductivity $(\mathrm{W} / \mathrm{m} / \mathrm{K})$, and heat production $\left(\mu \mathrm{W} / \mathrm{m}^{3}\right.$; Correia and Ramalho 2005).

\section{The case study of Neves-Corvo, IPB (Portugal)}

\section{Regional geology}

The IPB is a metallogenetic province about $250-\mathrm{km}$ long and $20-70 \mathrm{~km}$ wide (Oliveira et al. 2013), located in the SW part of the Iberian Peninsula, between Seville (Andalusia, Spain) and Marateca (Alentejo, Portugal). It is one of the most important volcanogenic massive sulfide districts in the world and its mining history dates back to 
5,000 years. In the Tartessian and Roman times, this area comprised very important copper, gold, and silver mines (e.g., Aljustrel and Rio Tinto). The modern mining started in the 1850s. At present, active mining occurs in Spain at Las Cruces, Águas Teñidas, and Cerro Colorado mines and in Portugal at Aljustrel and Neves-Corvo mines. The main targets are the base metals (copper, zinc, and lead) and precious metals (gold and silver; Tornos et al. 2008). The IPB contains a total of 1,850 Mt of sulfide deposits (1,600 Mt massive sulfide and $250 \mathrm{Mt}$ stock work) represented by 11 deposits in Portugal and 80 deposits in Spain (Oliveira et al. 2013). This is one of the largest crustal sulfur anomalies and hosts many of the largest concentration of massive volcanic sulfide deposits worldwide (Inverno et al. 2015a). The Neves-Corvo deposit exploited by Somincor/Lundin Mining is the main IPB mining area, with seven massive ore lenses identified Neves, Corvo, Graça, Zambujal Lombador, Semblana, and Monte Branco, the last two still in exploration phase (Oliveira et al. 2013; Owen and Meyer 2013). The Neves-Corvo underground mining is being developed down to 900-m depth. At surface, minimum environmental impact occurs, considering the modern mining techniques developed by the Somincor mine company.

Geologically, the IPB belongs to the South Portuguese Zone (SPZ) main Variscan domain (Oliveira et al. 2013). It was formed during the Variscan orogeny with the SPZ terrain and the Ossa-Morena terrain oblique collision. The result of this tensional tectonics was the pull-apart basins, which triggered submarine volcanism in the area. This volcanism was episodic, it has three felsic and two mafic cycles between them (de Oliveira et al. 2011), which are intercalated with sediments.

The deformation of the IPB during the Variscan orogeny is characterized by southto southwest-verging folds. In the region, there are several main antiform structures, with the axis of the antiforms located along the distinct volcanic axis. The RosárioNeves-Corvo is one of them, with a complex antiform area characterized by several thrusts faults with southwest vergency (Fig. 1). The IPB consists of two branches; the northern part built up by autochthonous and parautochthonous successions, whereas the southern part comprises rooted anticline structures (Pereira et al. 2008a; Oliveira et al. 2013).

\section{Succession of the SPZ}

The succession (Fig. 2) of the area is built up by three major units, from bottom to top the Phyllite-Quatrzite Group (PQG), the volcano-sedimentary complex (VSC), and the Baixo Alentejo Flysch Group (BAFG, where the Mértola Formation is included). The PQG build up dominantly black and grey shales in which are interbedded quartzites, quartz wacke siltstones, rarely conglomerates, and limestones. It is from Middle to Late Devonian age and owns shallow marine depositional environment, indicating a stable epicontinental platform. It is the IPB siliciclastic basement.

On the other hand, the VSC is dominated by shales, thin-bedded siltstones, and minor volcanic sediments and later felsic (rhyolite, rhyodacites, and dacites) and mafic (basalt and dolerites) volcanic rocks with minor andesite. The occurrence of 


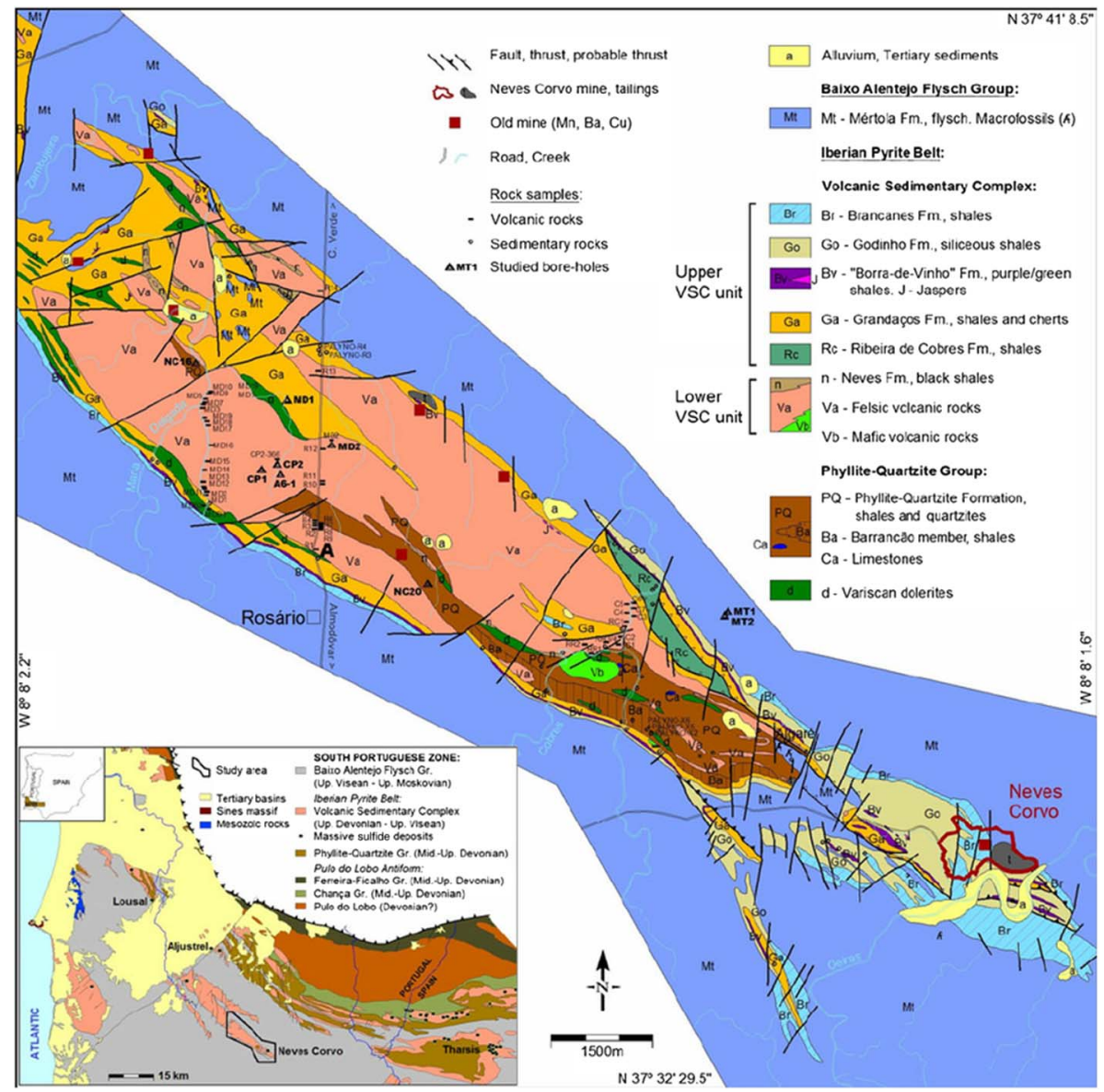

Fig. 1

Regional geology map of the Neves-Corvo project area (Oliveira et al. 2013)

the felsic volcanic rocks, dominantly lava/dome complexes, is associated with minor pyroclastic flows and intrusions. The felsic volcanic units and/or black shales host the massive sulfide deposits. The volcanic sequence can reach the 1,300-m thickness and is from Late Devonian-Early Carboniferous age. It was formed in an extensional graben-type basin on a disrupted siliciclastic platform (Oliveira et al. 2013; Inverno et al. 2015b).

The BAFG is a turbiditic sequence of shales, graywackes, and rare conglomerates. It is from Carboniferous age and represents the synorogenic foreland flysch associated with Variscan collision and tectonic inversion (Oliveira et al. 2013; Inverno et al. 2015b). 


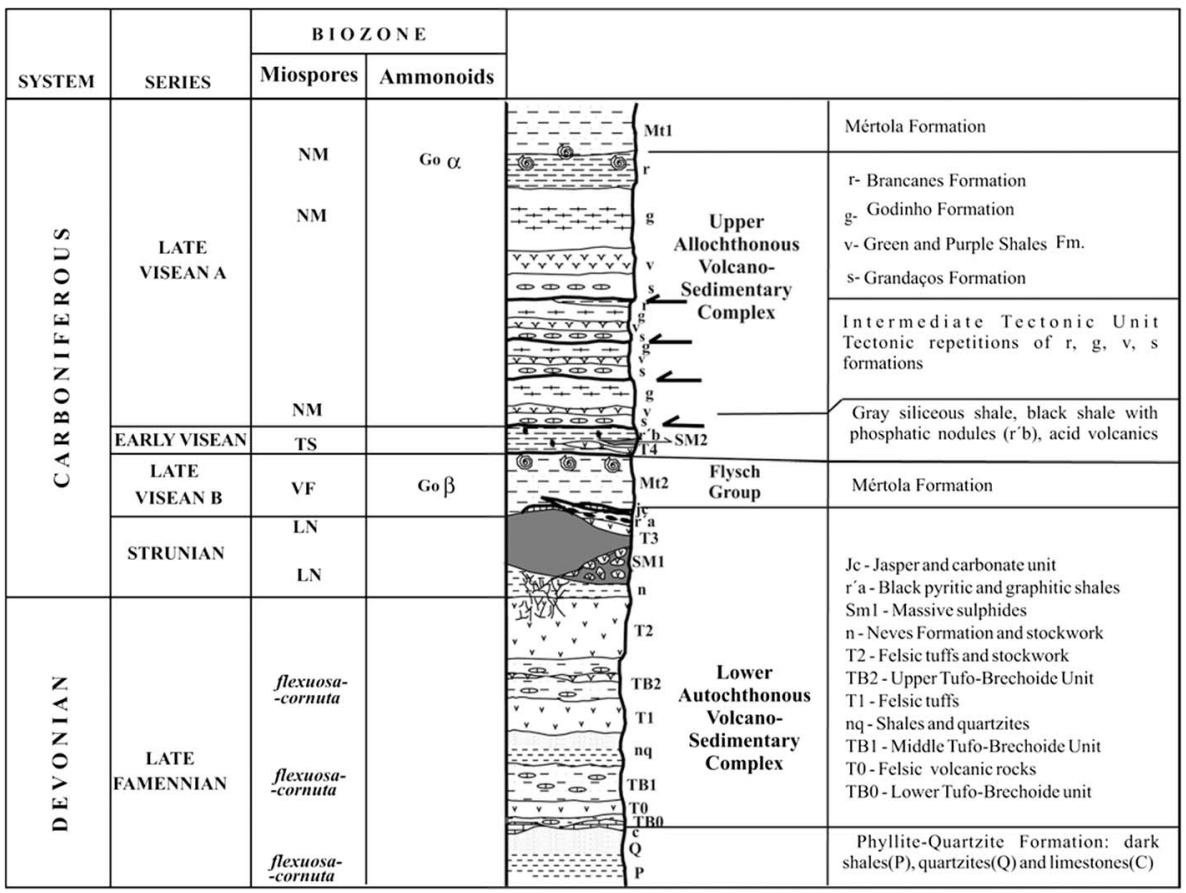

Fig. 2

Tectono-stratigraphic sequence of the Neves-Corvo mine area (Oliveira et al. 2004)

\section{Mineralization of the Neves-Corvo deposit}

The Neves-Corvo is one of the active mining areas of the Portuguese IPB sector. The giant deposit ( $>400 \mathrm{Mt}$ ) is represented by massive and stockwork ores (Batista et al. 2014; Carvalho et al. 2017) mined in the following ore lenses: Neves, Corvo, Graça, Zambujal, and Lombador. It was discovered in 1977 through a gravimetric survey, since the massive sulfides have higher density than the host rocks. The Neves-Corvo sulfide ores are associated with the lower sequence of the VSC and the mineralization with black shales of Strunian age (Pereira et al. 2008b; Matos et al. 2011; Oliveira et al. 2013).

The sulfide mineralization genesis is related to hydrothermal fluid circulation, in the volcanic and sedimentary host rocks (Barriga et al. 1997). The IPB deposits were formed by the bimodal submarine volcanism and the convective cells of the hydrothermal system related to it (Inverno et al. 2015a), and the deformational shear corridor of the Neves-Corvo main thrust controls the mineralization and the concentration of the copper-rich ore (Inverno et al. 2015b). The main metal is the copper, and the zinc is additional; other elements that appear in the Neves-Corvo ore body are tin, lead, silver, gold, and indium. Primary mineralization includes pyrite, chalcopyrite, sphalerite, and 
cassiterite; secondary minerals are arsenopyrite, galena, gold, silver, and tennantite [Sistema de Informação de Ocorrências e Recursos Minerais Portugueses (SIORMINP); LNEG 2016; Relvas et al. 2006]. The estimated resources (http://www.lundinmining. com/i/pdf/2015RandR.pdf, June 30, 2015) of the deposit are 25.9 Mt copper-rich and 25.3 Mt zinc-rich ores, which are close to the inferred in the report of Owen and Meyer (2013) (25,423 Mt copper ore with $1.7 \% \mathrm{Cu}$ and 22,060 Mt zinc ore with $4.5 \% \mathrm{Cu}$ ). The average element concentrations are shown in Table 1 . The expected life of the mine from the estimated resources is more than 10 years (Lundin Mining 2016).

\section{Hydrogeology}

The area is built up by low-permeability Paleozoic and Mesozoic volcanic rocks. During the Variscan orogeny faults, thrusts and folds developed significant permeability in these rocks (Fernández-Rubio et al. 1988). Infiltrating rainwater and the water of the Oeiras River are the main water sources through faults and fractures (Fernández-Rubio and Carvalho 1993). Fernández-Rubio et al. (1988) distinguished the following three main hydrological units:

- Cutaneous complex, which includes the alluvial terrace and weathered zone. In this case, permeability decreases with the depth.

- Intermediate complex, including the Flysch Group above the orebody. This unit has secondary permeability due to faults and fractures.

- The third zone is the Ore System, which includes the deposits and the footwall formation. The permeability of the zone is characterized by microfissures in the orebodies.

\section{Geothermal properties of the area}

There is a theoretical potential estimation for an enhanced geothermal system (EGS; Chamorro et al. 2014) for the entire Iberian Peninsula also covering the IPB. Temperature estimations reached different depths (up to 9,500 m), based on the heat-flow density and the heat production (Chamorro et al. 2014). However, the Portuguese National Geothermal Atlas (PNGA; Ramalho 2014) does not reach such depths, since other types of geothermal information are needed to make assumptions at depths near $10 \mathrm{~km}$. Therefore, as seen in the PNGA, surface heat-flow density shows relatively high variation in small distances near the IPB, but the small-scale variations

Table 1

Average element concentrations in the Neves-Corvo deposit

\begin{tabular}{lcccc}
\hline & $\mathrm{Cu}(\%)$ & $\mathrm{Zn}(\%)$ & $\mathrm{Pb}(\%)$ & $\mathrm{Ag}(\mathrm{g} / \mathrm{t})$ \\
\hline Copper-rich ore body & 2.7 & 0.8 & 0.2 & 37 \\
\hline Zinc-rich ore body & 0.4 & 7.1 & 1.7 & 66 \\
\hline
\end{tabular}


are more likely to be correlated with crustal composition than changes in the underlying heat flow. The surface heat-flow density of the SPZ [mainly measured in mining wells (triangles), water wells (blue dots), hydrocarbon wells (crosses), geothermal wells (squares), and in thermometric wells (pentagons) in the area shown in Fig. 3] varies between 60 and $100 \mathrm{~mW} / \mathrm{m}^{2}$ (Fernández et al. 1998; Correia and Ramalho 1999), and the mean value of the Peninsula is $73.3 \mathrm{~mW} / \mathrm{m}^{2}$ (Chamorro et al. 2014). In the case of Neves-Corvo, the mean value is $80 \mathrm{~mW} / \mathrm{m}^{2}$ as shown in Fig. 3, which belongs to the suitable areas in the mainland of Portugal. The mean radiogenic heat production value of the area is $2.93-3 \mu \mathrm{W} / \mathrm{m}^{3}$ (Fernández et al. 1998; Correia and Ramalho 1999; Chamorro et al. 2014), but it decreases with the depth (Correia and Ramalho 1999). This increase in depth indicates that for the study area, temperatures at 2 and $5 \mathrm{~km}$ depths are 64 and $130^{\circ} \mathrm{C}$, respectively. The available energy for an EGS power plant is stored in the range of 3-10 km depth (Chamorro et al. 2014).

The estimated temperature in Neves-Corvo is $100-150{ }^{\circ} \mathrm{C}$ at $3,500-\mathrm{m}$ depth and 150-200 ${ }^{\circ} \mathrm{C}$ at 5,500-m depth (Chamorro et al. 2014), which is suitable for an EGS project. Since 2015, on the GeoPortal of LNEG, more detailed data have been available from the area shown in Figs 4 and 5 (LNEG 2015). The temperature at $2,000 \mathrm{~m}$ is $63-65{ }^{\circ} \mathrm{C}$ and at $5,000 \mathrm{~m}$ is $131-134{ }^{\circ} \mathrm{C}$.

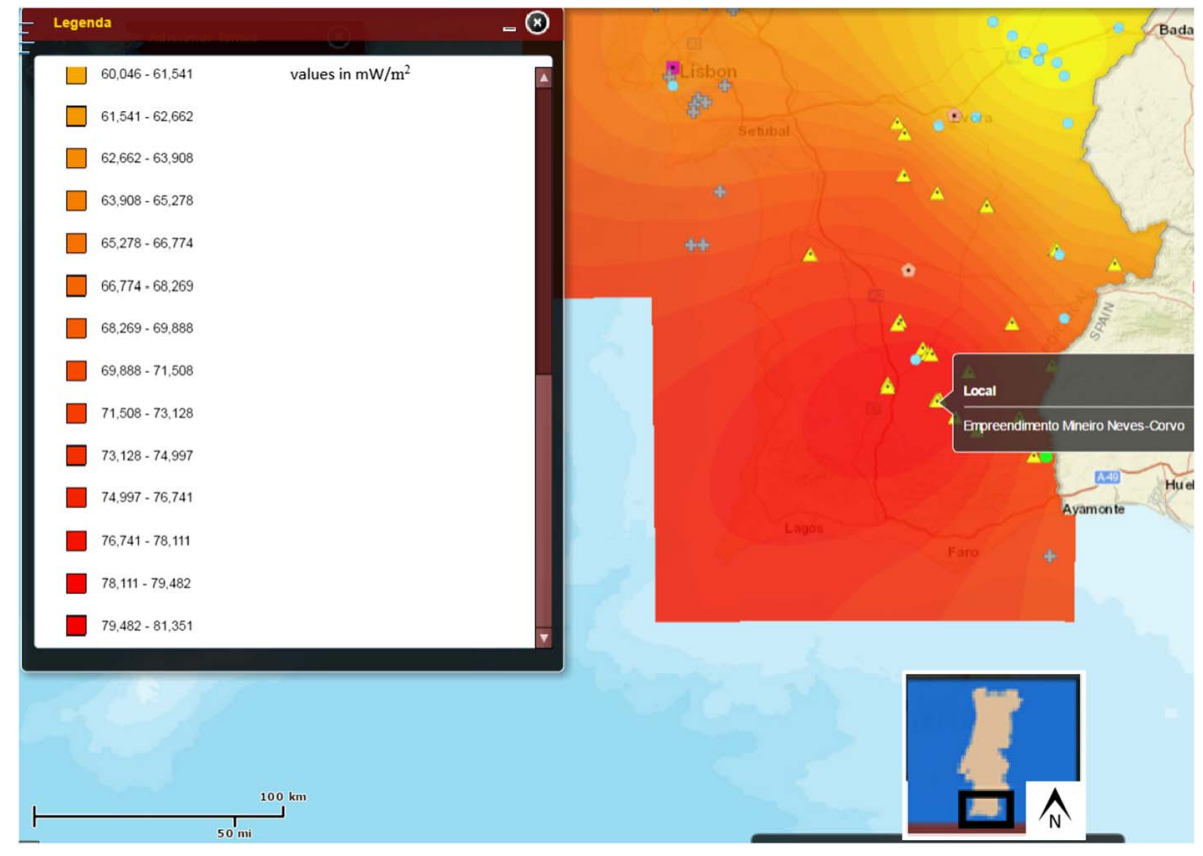

Fig. 3

Surface heat-flow density map of the South Portuguese Zone, showing the location of the Neves-Corvo mine and the origin of the data (LNEG 2015) 


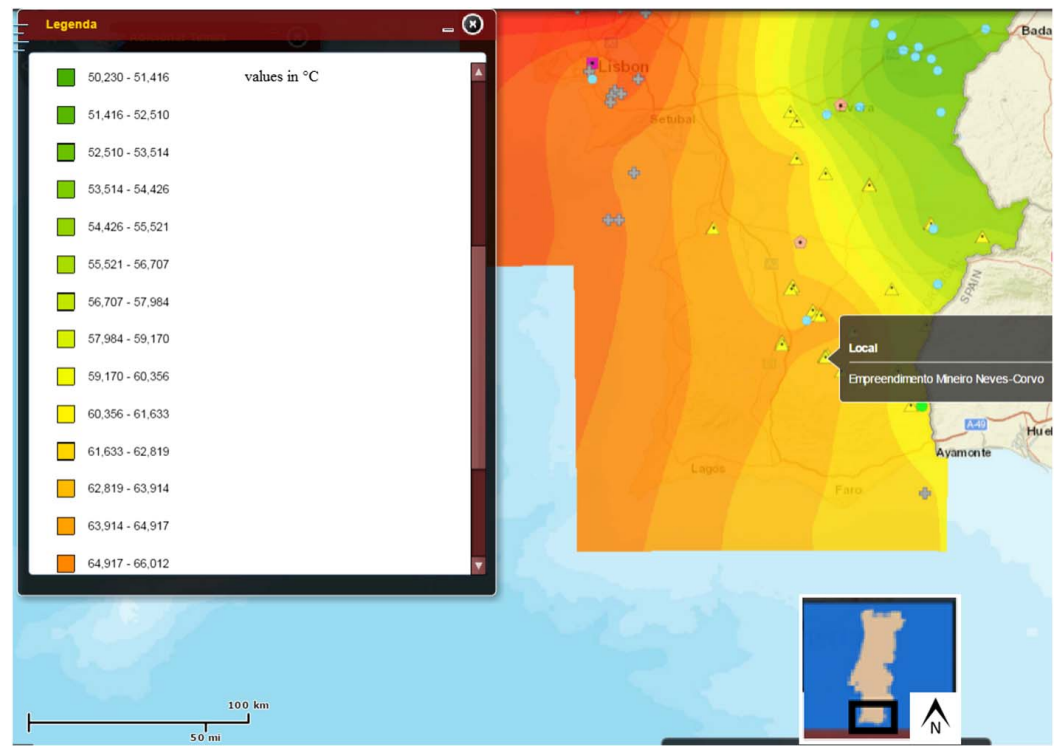

Fig. 4

Map of temperature at 2,000-m depth for the South Portuguese Zone, showing the location of the NevesCorvo mine and the origin of the data (LNEG 2015)

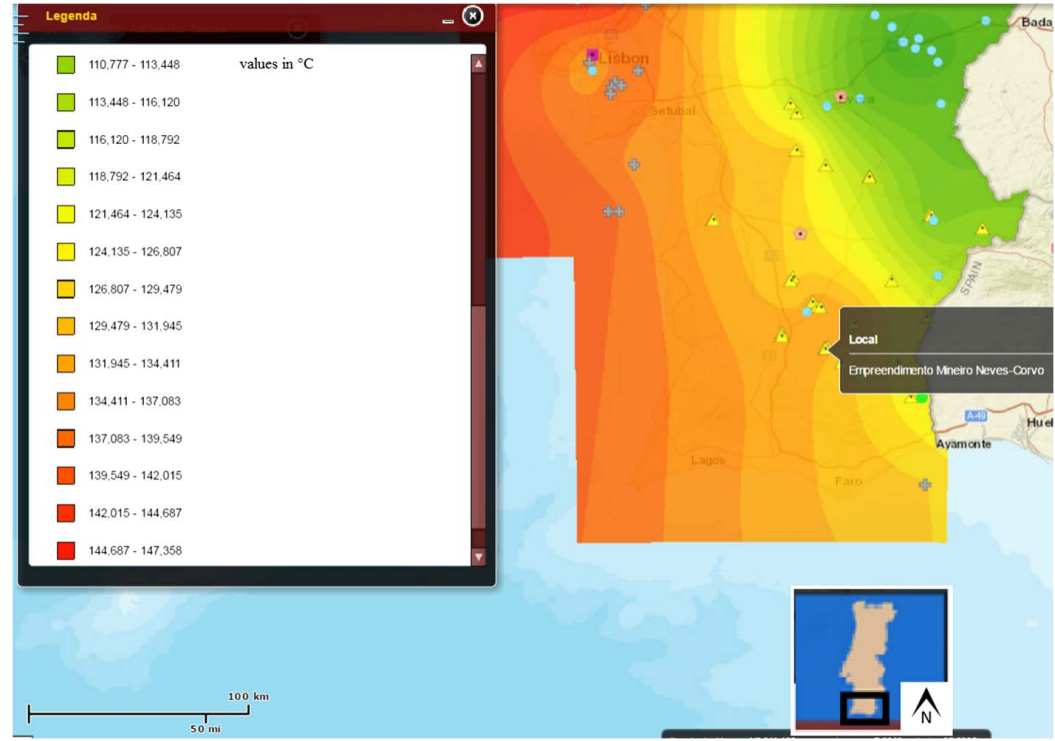

Fig. 5

Map of temperature at 5,000-m depth for the South Portuguese Zone, showing the location of the Neves-Corvo mine and the origin of the data (LNEG 2015) 


\section{The case study of Recsk (Hungary)}

\section{Geological background}

The Recsk ore complex is located in Northern Hungary, $120 \mathrm{~km}$ east from Budapest, in Mátra Mountains. Copper ore was mined on the Lahóca Hill for 130 years and a flotation plant was in operation until 1979. A deep-seated orebody was discovered in the 1960s and new underground exploration shafts and drifts were opened and maintained until 1984 (Földessy and Szebényi 2008). The total production of copper ore was $3.1 \mathrm{Mt}$, which has $0.61 \% \mathrm{Cu}$ and $2.5 \mathrm{mg} / \mathrm{kg}$ Au content (Baksa et al. 1980).

The Darnó Line, which is a major tectonic zone of Hungary, is the dominant structure in the area. It was active and produced strike-slip faults in the pre-Tertiary period (Seres-Hartai 1998). Due to this regional scale deformation zone, the basement sequence is separated into two essentially different structures: the folded Mesozoic of the Eastern Mátra Mountains and the faulted Mesozoic structural belt of Western Mátra Mountains (Fig. 6). The structural differences between the two units separated by this zone have been maintained throughout the Tertiary period (Tóth and Bobok 2007).

According to Seres-Hartai (1998), "The oldest formations of the Recsk area are Triassic limestone, quartzite and shales. After a long gap, the Paleogene series starts

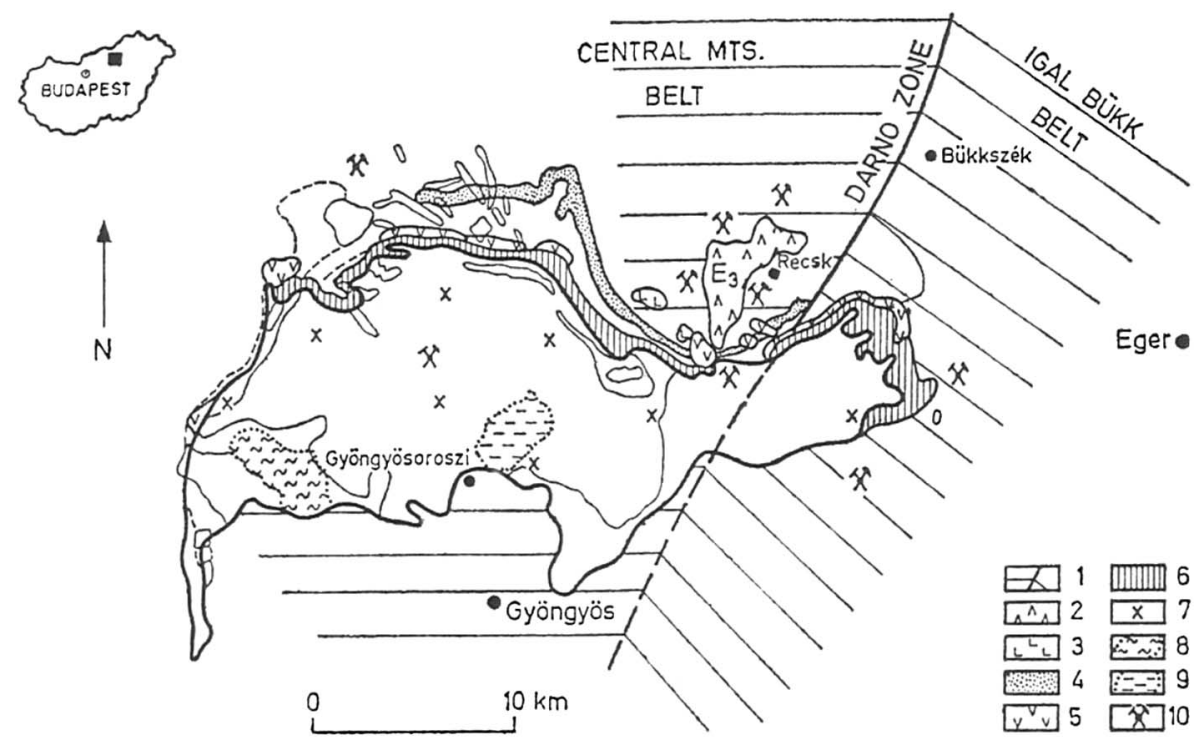

Fig. 6

Geology of the Mátra Mountains [1: Basement formations, 2: Upper Eocene biotite-hornblende andesites, 3: Eggenburgian andesites, 4: Lower rhyolite tuffs, 5: Carpathian pyroxene andesites, 6: Middle rhyolite tuffs, 7: Badenian pyroxene andesites, 8: Diatomites (caldera stage sediments), 9: Hydroquartzites (caldera stage), and 10: Mining area (after Földessy 1996; Illés et al. 2012)] 
with Upper Eocene marine limestone and marl. The formation of these sediments was followed by intrusive and volcanic events. Opposite to the main part of the Mátra Mountains, where Neogene events produced volcanic mass, the igneous activity took place during the Paleogene period, along a N-S trend shear zone in the Recsk area." The same author states that the age of magmatism is determined to be Upper Eocene by the underlying, intermingling, and overlying sediments of Eocene and Early Oligocene fossiliferous horizons (Less et al. 2008).

The ore-forming processes in the region took place at temperatures between 150 and $400{ }^{\circ} \mathrm{C}$. Two main mineralization stages can be separated: one of them comprises the mineralization of the intrusive host rock and the other one is coupled to the latest effusive (Földessy and Szebényi 2008).

\section{Hydrogeology}

Based on the examinations of Somody et al. (2008), data from observation wells could be used to describe groundwater conditions during flooding of the underground workings after mine closure (Somody 2000). As it is mentioned in the geological background subchapter, Darnó Line (and Darnó Structural Zone) has an important geological feature, as it has effect on the hydraulic conductivity. Through this zone, there is very little or no hydraulic connection at all; therefore, areas on the two sides are hydrologically independent (Szilágyi 1975). In the hydrogeological point of view, there are four main geological formations at the Recsk Deep Mines:

- internal core, formed by Eocene subvolcanic andesite (diorite) hosting porphyry $\mathrm{Cu}$ mineralization;

- transitional zone, coinciding with the skarn mineralization;

- external zone, generally called the "limestone" (limestone with limestone breccia and quartzite with quartzite breccia);

- cover rocks: Tertiary clastic sedimentary rocks and strato-volcanic andesite tuff.

These structural properties fundamentally determine permeability, transmissivity, and water-yield of the water-bearing units. As it was measured in exploration, boreholes data are shown in Table 2.

\section{Geothermal properties of the area}

During mercury thermometer measurements of the upper drift level $960 \mathrm{~m}$ below the surface, the corrected average temperature was $51.8^{\circ} \mathrm{C}$. The average temperature at the lower roadway level $1,160 \mathrm{~m}$ under the surface was $59.5^{\circ} \mathrm{C}$. According to these values, the geothermal gradient is $38.5^{\circ} \mathrm{C} / \mathrm{km}$. Above the drift, the main rock types are Upper Eocene-Lower Oligocene andesite and Triassic limestone. The average heat conductivity of these rock units is $2.53 \mathrm{~W} / \mathrm{m} / \mathrm{K}$. Therefore, the heat flow calculated from these data is $97 \mathrm{~mW} / \mathrm{m}^{2}$ (Tóth 2011). This is slightly higher than the average value in Hungary, which is $95 \mathrm{~mW} / \mathrm{m}^{2}$ (Fig. 7). 
Table 2

Hydraulic parameters of water-bearing formations in the Recsk Deep Mines

\begin{tabular}{lcccc}
\hline & Limestone & Skarn & Andesite & Average \\
\hline Water yield (average) $(1 / \mathrm{min})$ & 114.9 & 46.7 & 34.8 & 89.8 \\
\hline Specific water yield $(1 / \mathrm{min} / \mathrm{m})$ & 0.77 & 0.31 & 0.23 & 0.6 \\
\hline Transmissivity (average) $\left(\mathrm{m}^{2} / \mathrm{s}\right)$ & $1.1 \times 10^{-3}$ & $1.9 \times 10^{-5}$ & $8.8 \times 10^{-6}$ & $1.5 \times 10^{-4}$ \\
\hline Hydraulic conductivity $(\mathrm{m} / \mathrm{s})$ & $6.8 \times 10^{-6}$ & $1.2 \times 10^{-7}$ & $5.5 \times 10^{-8}$ & $1.0 \times 10^{-6}$ \\
\hline Pore volume (estimated) $(\%)$ & 1.0 & 0.5 & 0.1 & 0.5 \\
\hline
\end{tabular}

Data are not available for the Tertiary clastic sedimentary rocks, primarily clayey marl, which are essentially impermeable (modified after Szilágyi 2002; Somody et al. 2008)

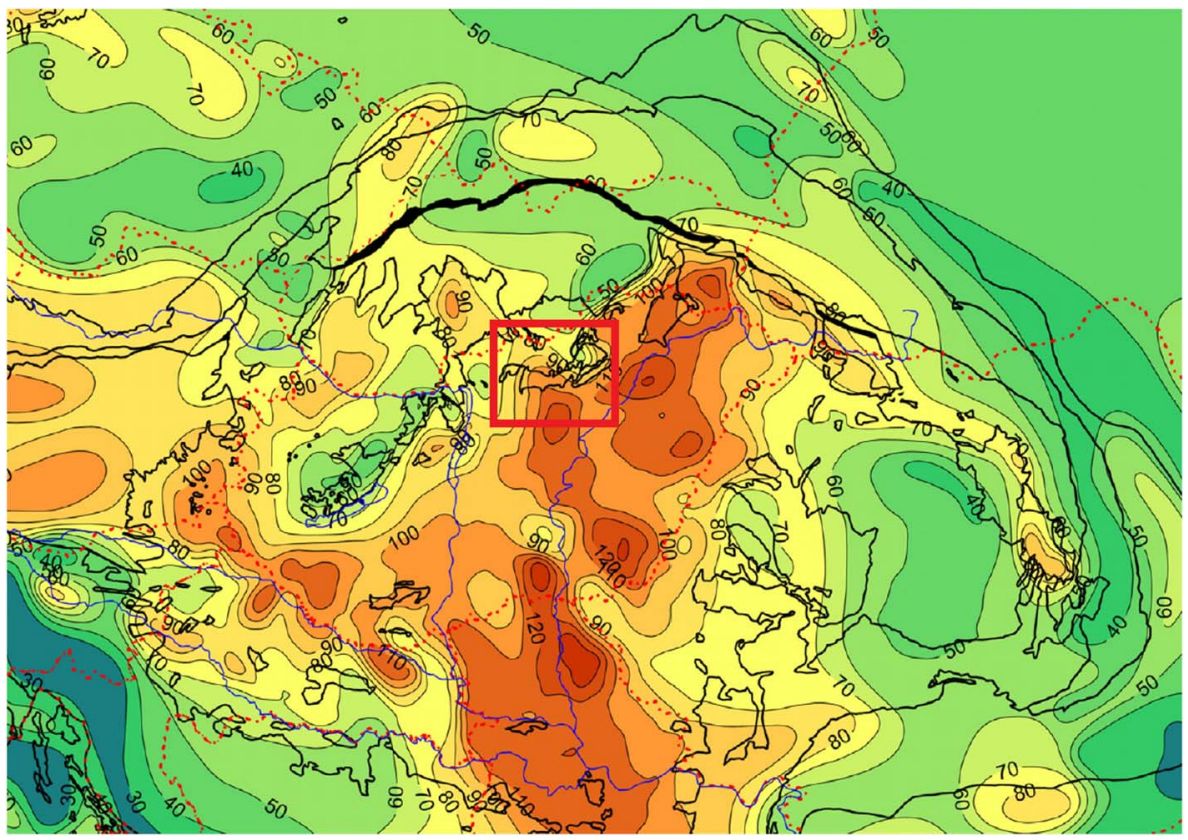

Fig. 7

Heat-flow map of the Pannonian basin and surrounding regions (heat-flow values in $\mathrm{mW} / \mathrm{m}^{2}$; modified after Horváth et al. 2015)

The flooded exploration facilities have a great geothermal potential, since the temperature of the water is the same as the temperature of the rock. According to Illés et al. (2012), the volume of the water in the flooded facilities is more than $200,000 \mathrm{~m}^{3}$. In the shaft, at the $1,160 \mathrm{~m}$, the temperature of the water is $59{ }^{\circ} \mathrm{C}$. Utilizing 
this temperature by a submersible pump, with $1.2 \mathrm{~m}^{3} / \mathrm{min}$ flow rate, the extractable heat would be $2,512 \mathrm{~kW}$, assuming the water temperature to be $30{ }^{\circ} \mathrm{C}$ (Illés et al. 2012).

As an example, Tóth and Bobok (2007) suggested a potential utilization as district heating in a nearby recreation area where there are health resorts and hotel facilities. Heat pumps should be applied to increase the temperature of the water for this kind of use (Hall et al. 2011).

\section{Discussion}

\section{Comparison of the geology and ore formation of the two deposits}

The Neves-Corvo and the Recsk mining areas have similar tectonic setting, both located in a shear tectonic zone (Neves-Corvo main thrust and Darnó Zone). The two deposits are associated with volcanic and sedimentary rocks.

The Neves-Corvo mineralization was developed as the result of the hydrothermal system associated with volcanism during the Variscan orogeny. The deposit consists of high-grade copper $(2.7 \%)$ and high-grade zinc-rich $(7.1 \%)$ ores (SIORMINP; LNEG 2016).

The Recsk deposit is associated with the Eocene and Early Oligocene volcanic events, in the shear system of the Darnó Zone. The volcanism varied from subaqueous to stratovolcanic. The mineralization is associated with the shallow intrusive porphyric body and its skarn environment and intensive hydrothermal alteration (Földessy and Szebényi 2008).

Neves-Corvo is an active mining area with underground exploitation. The shaft diameter is $5 \mathrm{~m}$ and the depth of the mine is about $700 \mathrm{~m}$ (Owen and Meyer 2013). The mining area is about $2,500 \mathrm{~m} \times 2,500 \mathrm{~m}$, with $\sim 400 \mathrm{Mt}$ ore body (Owen and Meyer 2013). The massive ore mineralization contains vein network, stock work, and disseminated ores hosted by volcanic (rhyolite) and sediment (shales) rocks. On the other hand, Recsk is in post-mining phase (the deep-seated mineralizations were explored, but not exploited). The exploitation of the near surface epithermal zone was underground, the diameter is $8 \mathrm{~m}$, and the depth of the mine is about 1,202 $\mathrm{m}$ (Tóth and Bobok 2007). The mining area is $1,800 \mathrm{~m} \times 1,400 \mathrm{~m}$, with a $35.5 \mathrm{Mt}$ of gold in lower grade and 16.5 Mt of gold in higher grade, besides the high-grade copper (Seres-Hartai 1998). The mineralization contains disseminated ores and veins hosted by limestone and andesite.

The deep-seated zone was only exploration area, and the near surface exploited area may not be suitable for geothermal utilization. In Neves-Corvo, the massive mineralization can be suitable for geothermal purposes.

\section{Geothermal comparison}

The available data show good opportunity to utilize the heat stored in the rocks. The temperature at about $1,000 \mathrm{~m}$ is $51.8^{\circ} \mathrm{C}$ in Recsk (at $960 \mathrm{~m}$; Tóth and Bobok 2007), 


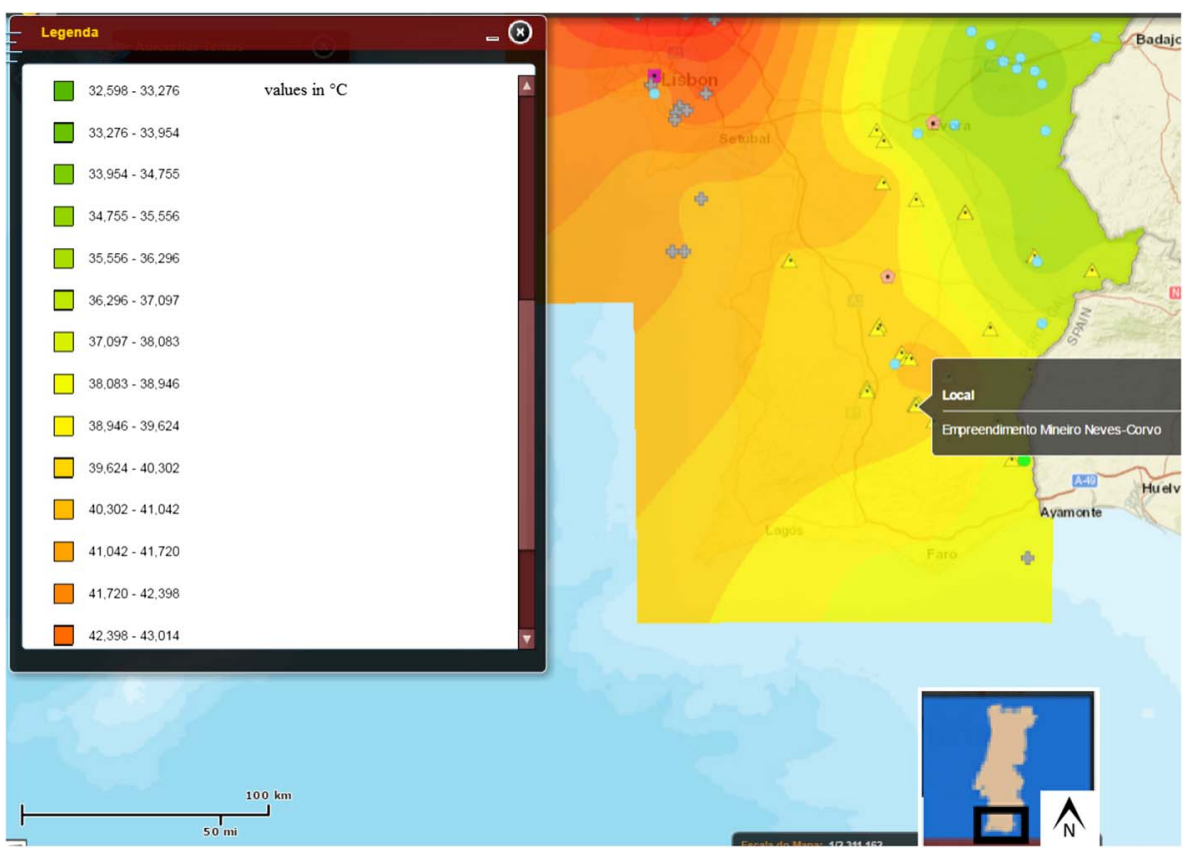

Fig. 8

Temperature at 1,000-m depth map of the South Portuguese Zone, showing the location of the Neves-Corvo mine and the origin of the data (LNEG 2015)

whereas at the same depth, it is around $40{ }^{\circ} \mathrm{C}$ (Fig. 8; Chamorro et al. 2014) in Neves-Corvo. The heat-flow density values are higher than the world average. In the case of Neves-Corvo, it is about $80 \mathrm{~mW} / \mathrm{m}^{2}$ (Fig. 3; Correia and Ramalho 1999; Chamorro et al. 2014) and in case of Recsk, it is $97 \mathrm{~mW} / \mathrm{m}^{2}$ (Fig. 7; the geothermal gradient is $38.5^{\circ} \mathrm{C} / \mathrm{km}$; Tóth and Bobok 2007).

In Recsk during the development of the exploration facilities, there were water inrushes with the flow rate of 0.98 and $2 \mathrm{~m}^{3} / \mathrm{min}$ and it has high salinity $\left(9,000 \mathrm{gm}^{-3}\right)$, thus the area may have natural water support.

In the case of Neves-Corvo, thermal estimations show that the temperature for an energy production or urban heating is given in the area. Between 3,500- and 4,500-m depth, the temperature is sufficient for electricity generation by a geothermal power plant (Chamorro et al. 2014). Above this depth, the heat source is enough for urban heating, spas, or hotels. At present, there is no geothermal utilization in any of these areas, although they can be promising for these kinds of projects.

\section{Potential}

Overall, the geothermal potential from the data presented by Tóth and Bobok (2007) and Chamorro et al. (2014) is greater in the case of Recsk, whereas the ore 
potential shows the contrary; the amount of extractable metals is smaller. In the area of Neves-Corvo, exploration for an EGS system goes down to the depth of $10 \mathrm{~km}$ (Chamorro et al. 2014), while Recsk should have these kinds of surveys to see the potential for a similar project.

Both areas seem to be promising for energy production or for spas, hotels, or urban heating (it can be changed periodically with the demand) in the geothermal point of view and for metal extraction as well.

However, these projects can lead to change in porosity and permeability of affected areas; thus, the hydrological and hydrogeological planning and monitoring are important not only for a sustainable mining but also for environmental protection.

\section{Conclusions}

Europe needs energy and strategic mineral resources. Thus, the targets of the geothermal energy projects may be the mineral deposits in the future (CHPM2030 project). The geothermal power is a renewable energy source with a minimum environmental impact and higher capacity factor (electricity generated for a period) than other type of power plants (Chamorro et al. 2014). Moreover, the metal extraction associated with it will generate less environmental impact than the traditional (surface or underground) mining. The potential of these two deposits can be interesting in the development of this kind of projects, if technology is ready to build a pilot system.

\section{Acknowledgements}

This study was supported by the ERASMUS program through Laboratório Nacional de Energia e Geologia (LNEG) and University of Miskolc. The authors would like to thank Éva Hartai who helped a lot during the preparation and the publishing of the article.

\section{References}

Árpási, M. 2003: Geothermal development in Hungary - Country update report 2000-2002. - Geothermics, 32, pp. 371-377.

Baksa, C., J. Cseh-Németh, J. Csillag, J. Földessy, T. Zelenka 1980: The Recsk porphyry and skarn copper ore deposit, Hungary. - In: Jankovic, S., R. Sillitoe (Eds): European Copper Deposits. Belgrade University, Belgrade, pp. 73-76.

Barriga, F.J.A.S., D. de Carvalho, A. Ribeiro 1997: Introduction to the Iberian Pyrite Belt. - SEG Neves Corvo Field Conference, Guidebook Series, 27, 20 p.

Batista, M.J., P. Represas, J.X. Matos, C. Inverno 2014: 3D predictive modelling using drill-hole geochemistry and gravity inversion. First approach using data from Neves-Corvo mining area, Iberian Pyrite Belt. - Comunicações Geológicas, 101/II, pp. 747-752.

Carvalho, J., C. Inverno, J.X. Matos, C. Rosa, I. Granado, T. Branch, P. Represas, L. Carabaneanu, L. Matias, P. Sousa 2017: Subsurface mapping in the Iberian Pyrite Belt using seismic reflection profiling and potential field data. - International Journal of Earth Sciences, 106/3, pp. 899-915. 
Chamorro, C.R., J.L. García-Cuesta, M.E. Mondéjar, M.M. Linares 2014: An estimation of the enhanced geothermal systems potential for the Iberian Peninsula. - Renewable Energy, 66, pp. 1-14.

Correia, A., E.C. Ramalho 1999: One-dimensional thermal models constrained by seismic velocities and surface radiogenic heat production for two main geotectonic units in southern Portugal. - Tectonophysics, 306, pp. 261-268.

Correia, A., E.C. Ramalho 2005: Updated surface heat flow density map in Mainland Portugal. Proceedings of the World Geothermal Congress, Antalya, $5 \mathrm{p}$.

Correia, A., E.C. Ramalho 2010: Update heat flow density map for Portugal. - Proceedings of the World Geothermal Congress, Bali, 7 p.

de Oliveira, D.P.S., J.X. Matos, C.J.P. Rosa, D.R.N. Rosa, M.O. Figueiredo, T.P. Silva, F. Guimarães, J.R.S. Carvalho, A.M.M. Pinto, J.R.M.S. Relvas, F.K.M. Reiser 2011: The Lagoa Salgada orebody, Iberian Pyrite Belt, Portugal: Geology, distribution, mineralogy and geochemistry of Indium. - Economic Geology, 106, pp. 1111-1128.

Dickson, M.H., M. Fanelli (Eds) 2003: Geothermal Energy: Utilization and Technology. - UNESCO, Paris, $224 \mathrm{p}$.

Fernández, M., I. Marzán, A. Correia, E. Ramalho 1998: Heat flow, heat production, and lithospheric thermal regime in the Iberian Peninsula. - Tectonophysics, 291, pp. 29-53.

Fernández-Rubio, R., P. Carvalho 1993: Surface water inflow reduction at the underground Neves-Corvo mine, Portugal. - Mine Water and the Environment, 12/1, pp. 11-20.

Fernández-Rubio, R., P. Carvalho, F. Real 1988: Mining hydrogeological characteristics of the underground copper mine of Neves-Corvo, Portugal. - Third International Mine Water Congress, Melbourne, $15 \mathrm{p}$.

Földessy, J. 1996: Lahóca epithermal gold deposit, Recsk-Hungary. Plate tectonic aspects of the Alpine metallogeny. - Proceedings of the Annual Meeting, Sofia, pp. 67-74.

Földessy, J., G. Szebényi 2008: The mineralization of the Recsk Deeps and Lahóca - Short geological overview. - Publications of the University of Miskolc, Series A: Mining, 73, pp. 85-98.

Hall, A., J.A. Scott, H. Shang 2011: Geothermal energy recovery from underground mines. - Renewable and Sustainable Energy Reviews, 15/2, pp. 916-924.

Horváth, F., B. Musitz, A. Balázs, A. Végh, A. Uhrin, A. Nádor, B. Koroknai, N. Pap, T. Tóth, G. Wórum 2015: Evolution of the Pannonian basin and its geothermal resources. - Geothermics, 53, pp. 328-352.

Hurter, S.J., R. Haenel (Eds) 2002: Atlas of Geothermal Resources in Europe. - GGA, Hannover, 270 p.

Illés, B., J. Zsuga, A. Tóth 2012: Energy transport and potential of an abandoned mine. - Advanced Logistic Systems, 6/1, pp. 127-132.

Inverno, C., A. Diez-Montes, C. Rosa, J. García-Crespo, J.X. Matos, J.L. García-Lobón, J. Carvalho, F. Bellido, J.M. Castello-Branco, C. Ayala, M.J. Batista, F. Rubio, I. Granado, F. Tornos, J.T. Oliveira, C. Rey, V. Araújo, T. Sánchez-García, Z. Pereira, P. Represas, A.R. Solá, P. Sousa 2015a: Chapter 9 - Introduction and geological setting of the Iberian Pyrite Belt. - In: Weihed, P. (Ed): 3D, 4D and Predictive Modelling of Major Mineral Belts in Europe. Springer, Cham, pp. 191-208.

Inverno, C., C. Rosa, J.X. Matos, J. Carvalho, J.M. Castello-Branco, M.J. Batista, I. Granado, J.T. Oliveira, V. Araújo, Z. Pereira, P. Represas, A.R. Solá, P. Sousa 2015b: Chapter 11 - Modelling of the NevesCorvo Area. - In: Weihed, P. (Ed): 3D, 4D and Predictive Modelling of Major Mineral Belts in Europe. Springer, Cham, pp. 191-208.

Less, Gy., M. Beke-Báldi, S. Pálfalvi, J. Földessy, B. Kertész 2008: New data on the Recsk volcanics and of the adjacent sedimentary rocks. - Publications of the University of Miskolc, Series A: Mining, 73, pp. 57-84.

Lindal, B. 1973: Industrial and other applications of geothermal energy. - In: Armstead, H.C.H. (Ed): Geothermal Energy. UNESCO, Paris, pp. 135-148.

LNEG 2015: Geothermal Maps from the Neves-Corvo Area. - http:/geoportal.lneg.pt/geoportal/mapas/ index.html.

LNEG 2016: SIORMINP - Sistema de Informação de Ocorrências e Recursos Minerais Portugueses [Information System for Occurrences and Portuguese Mineral Resources]. - http:/geoportal.lneg.pt/ index.php?option=com_content\&id=69\&lg=en. 
Lund, J.W., T.L. Boyd 2016: Direct utilization of geothermal energy 2015 worldwide review. Geothermics, 60, pp. 66-93.

Lundin Mining 2016: Summary Report Neves-Corvo. - http://www.lundinmining.com/i/pdf/Summary_ Report_Neves-Corvo.pdf.

Matos, J.X., Z. Pereira, C.J.P. Rosa, D.R.N. Rosa, J.T. Oliveira, J.M.R.S. Relvas 2011: Late Strunian age: A key time frame for VMS deposit exploration in the Iberian Pyrite Belt. - 11th Biennial SGA Meeting, Antofagasta, pp. 790-792.

Oliveira, J.T., Z. Pereira, P. Carvalho, N. Pacheco, D. Korn 2004: Stratigraphy of the tectonically imbricated lithological succession of the Neves-Corvo mine area, Iberian Pyrite Belt, Portugal. - Mineralium Deposita, 39, pp. 422-436.

Oliveira, J.T., C.J.P. Rosa, Z. Pereira, D.R.N. Rosa, J.X. Matos, C. Inverno, T. Andersen 2013: Geology of the Rosário-Neves-Corvo antiform, Iberian Pyrite Belt, Portugal: New insights from physical volcanology, palynostratigraphy and isotope geochronology studies. - Mineralium Deposita, 48, pp. 749-766.

Owen, M.L., L. Meyer 2013: Lundin Mining. NI 43-101 Technical Report for Neves-Corvo Mine and Semblana Deposit, Portugal. - Wardell Armstrong, London, 224 p.

Pereira, Z., J.X. Matos, P. Fernandes, J.T. Oliveira 2008a: Devonian and Carboniferous palynostratigraphy of the South Portuguese Zone, Portugal - An overview. - Comunicações Geológicas, 94, pp. 53-79.

Pereira, Z., J.X. Matos, P. Fernandes, J.T. Oliveira 2008b: Palynostratigraphy and systematic palynology of the Devonian and Carboniferous successions of the South Portuguese Zone, Portugal. - Memórias Geológicas do INETI, 34, $181 \mathrm{p}$.

Pollack, H.N., S.J. Hurter, J.R. Johnson 1993: Heat flow from the Earth's interior: Analysis of the global data set. - Reviews of Geophysics, 31, pp. 267-80.

Ramalho, E.C. 2014: Geothermal Energy- State of the Art in Portugal. - Geothermal Energy Workshop, Salta, 25 p.

Relvas, J.M.R.S., F.J.A.S. Barriga, A. Ferreira, P.C. Noiva, N. Pacheco, G. Barriga 2006: Hydrothermal alteration and mineralization in the Neves-Corvo volcanic-hosted massive sulfide deposit, Portugal, I: Geology, mineralogy, and geochemistry. - Economic Geology, 101/4, pp. 753-790.

Seres-Hartai, É. 1998: Past and possible future of the Lahóca mine, Recsk, Hungary - A historical review. Acta Montanistica Slovaca, 2, pp. 123-128.

Somody, A. 2000: A recski Mélyszinti Bányaüzem feltölt dési folyamata és az azt ellen rz megfigyel rendszer kialakítása [Optimalization of monitoring system in the Recsk area]. - Ifjú Szakemberek Ankétja, 2001, p. 23. (in Hungarian)

Somody, A., Gy. Jordán, G. Szilágyi 2008: Surface water and groundwater hydrology and hydrogeochemistry in the Recsk mining area. - Publications of the University of Miskolc, Series A: Mining, 73, pp. 193-226.

Szilágyi, G. 1975: A recski mélyszinti ércesedés vízföldtani helyzete [Hydrogeology of the subvolcanic ore mineralization of Recsk]. - Földtani Közlöny, 105, pp. 740-754. (in Hungarian)

Szilágyi, G. 2002: A recski mélyszinti ércel fordulás víz- és gázföldtani körülményei [The hydrogeological and gas conditions of the Recsk Deeps mineralisation]. - Földtani Kutatás, 39/2, pp. 21-27. (in Hungarian)

Tornos, F., E. López Pamo, F.J. Sánchez España 2008: Chapter 4 - The Iberian Pyrite Belt. - In: GarciaCortes, A. (Ed): Spanish Geological Contexts: An Approach to the Spanish Geological Heritage of International Significance. Geological and Mining Institute of Spain, Madrid, pp. 56-64.

Tóth, A. 2011: Geothermal potential of an abandoned copper mine. - 2nd International Conference on Advances in Energy Engineering, Bangkok, 6 p.

Tóth, A., E. Bobok 2007: A prospect geothermal potential of an abandoned copper mine. - Proceedings of the Thirty-Second Workshop on Geothermal Reservoir Engineering, Stanford, 3 p. 